\title{
Investigation On Corrosion Behavior of Cryogenically Treated Friction Stir Welded AA5083
}

\author{
Vasudevan NEELAMEGAM*, Bhaskar GOVINDASAMY BHAVANI**, Mohandass \\ MUTHUKRISHNAN***, Srinivasa Rao TADIVAKA**** \\ *Department of Mechanical Engineering, Sri Sairam Engineering College, Chennai 600 073, Tamil Nadu, India, \\ E-mail: vasudevanneelam@gmail.com \\ **Department of Production Technology, Madras Institute of Technology, Anna University, Chennai 600 025, Tamil \\ Nadu, India \\ ***Department of Mechanical Engineering, Sri Venkateswara College of Engineering, Chennai 603 110, Tamil Nadu, \\ India \\ ****Department of Mechanical Engineering, Faculty of Science and Technology, ICFAI Foundation for Higher Educa- \\ tion, Hyderabad 501 203, Telangana, India

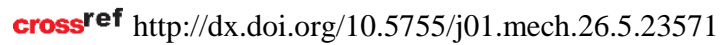

\section{Introduction}

Friction stir welding (FSW) [1] is an important new welding technique with potentially significant application in manufacturing industries such as aerospace, automotive, railway and marine. The process offers several benefits over the traditional fusion welding processes. FSW is done by rotating and plunging a specially-designed cylindrical, shouldered tool with a small diameter pin into the joint line between two butted plates. Frictional heat causes the metal to soften and allows the tool to move along the joint line. The FSW process generates three distinct micro-structural zones: the weld nugget (WN), the thermo-mechanically- affected zone (TMAZ) and the heat-affected zone (HAZ). The WN is the region through which the tool pin passes, and thus experiences high deformation and high heat. It generally consists of fine equiaxed grains due to full recrystallization. The TMAZ adjacent to the nugget is the region where the metal is plastically deformed as well as heated, but this is not sufficient to cause recrystallization. The HAZ experiences only a heating effect, with no mechanical deformation.

Aluminium alloy 5083 is a weld able, strain hardening structural material suitable for marine applications due its excellent formability, good strength and high corrosion resistance. Particularly, $8 \mathrm{~mm}$ and above is the typical thickness used in shipbuilding [2]. The H321 designation signifies strain hardened and stabilized condition. The alloy 5083 also has very good low temperature mechanical properties which make the alloy suitable for manufacturing liquid natural gas (LNG) carriers, tanks and cryogenic containers.

Friction stir welding of aluminum alloys has been a potential research area and extensively studied in the last almost two and a half decades. Comprehensive re-views carried out by Mishra and $\mathrm{Ma}$ [3] and Nandan et al. [4] revealed sizable amount of information on the effects of process parameters, variations in microstructures, and structure-property correlations. More recently, there have been a number of reports [5-10] highlighting the changes in microstructures, dissolution and coarsening of strengthening precipitates in the weld nugget and formation of wide precipitatefree zones in the heat affected zone due to the plastic defor- mation and frictional heat associated with FSW. Also, several investigators studied the corrosion behavior of friction stir welded aluminum alloys [11-15].

In recent years, a few researchers have confirmed the favourable effects of cryogenic treatment on various metallic alloys [16, 17]. The CT process consists of gradual cooling of samples to cryogenic temperatures, soaking at those temperatures for targeted time and slowly heating to room temperature. Some non-ferrous alloys such as titanium-um alloys [18], copper alloys [19] and aluminum alloys [20-22] have also been treated using this treatment to improve the properties. However, 5xxx series aluminum alloys have rarely been investigated for effects of cryogenic treatment. Specially, the alloy AA5083, which is a candidate material for cryogenic applications, has hardly been studied for possible effects of the CT. Furthermore, in view of the above literature survey, it seems there have been no attempts to study the effect of cryogenic treatment on corrosion properties of AA5083 friction stir welds. Furthermore, there has not been any systematic study ex-plaining the correlation between $\mathrm{pH}$ value of the salt solution, time of exposure and corrosion behavior of cryogenically treated AA5083 friction stir welds. Thus, in this investigation, the effect of cryogenic treatment on the salt fog corrosion behavior of $10 \mathrm{~mm}$ thick AA5083-H321 friction stir welds was evaluated while changing $\mathrm{pH}$ value of the salt solution and time of exposure.

\section{Experimental procedure}

The base material used in this study was $10 \mathrm{~mm}$ thick AA5083-H321 plates, having chemical composition as shown in Table 1. The plates were machined to get a size of $110 \mathrm{~mm}$ wide and $250 \mathrm{~mm}$ long and cleaned with acetone to remove oxide layer and other unwanted particles. Friction stir welding trials were performed using a specially designed milling machine (Fig. 1, a). The photograph of the welded joint is shown in Fig. 1, b. The details of tool geometry and welding parameters used in this study are presented in Table 2.

In order to study the effect of cryogenic treatment on corrosion properties of the base material and the friction stir welds, the samples were prepared to accommodate in the 
chamber and subjected to cryogenic treatment using a cryogenic chamber (Fig. 2). The illustration of cryogenic treatment is also shown in Fig. 3. The samples were placed into the cryogenic chamber, to ensure the temperature in the cryogenic range using liquid nitrogen, and slowly cooled down from room temperature to the target temperature of $-180^{\circ} \mathrm{C}$ at a cooling rate of $2^{\circ} \mathrm{C} / \mathrm{min}$. The samples were soaked for $2 \mathrm{~h}$ at target temperature. The samples were warmed up to room temperature at a heating rate of $2^{\circ} \mathrm{C} / \mathrm{min}$ to avoid thermal shock. The samples were then investigated in both untreated and treated conditions. For convenience, the samples in various conditions will henceforth be referred to as BM (un-treated base material), CT BM (cryogenic treated base material), FSW (untreated friction stir weld) and CT FSW (cryogenic treated friction stir weld).

Chemical composition of AA5083-H321 in wt. \%

Table 1

\begin{tabular}{|c|c|c|c|c|c|c|c|c|c|}
\hline Material & $\mathrm{Mg}$ & $\mathrm{Mn}$ & $\mathrm{Fe}$ & $\mathrm{Si}$ & $\mathrm{Ti}$ & $\mathrm{Zn}$ & $\mathrm{Cr}$ & $\mathrm{Cu}$ & $\mathrm{Al}$ \\
\hline AA5083 & 4.367 & 0.481 & 0.284 & 0.090 & 0.020 & 0.009 & 0.115 & 0.021 & remaining \\
\hline
\end{tabular}

Table 2

Details of tool geometry and welding parameters

\begin{tabular}{|c|l|}
\hline Nomenclature & \multicolumn{1}{c|}{ Process parameter } \\
\hline & M2 tool steel. Taper threaded pin (left hand metric threads, 1.5 mm pitch). Pin diameter: \\
Tool geometry & $8 \mathrm{~mm}$ (shoulder end) and 5 mm (tip end). Pin length: 9.7 mm. Shoulder diameter: $22 \mathrm{~mm}$. \\
& Flat shoulder \\
\hline Tool rotational speed & \multicolumn{1}{c|}{$750 \mathrm{rpm}$} \\
\hline Welding speed & $150 \mathrm{~mm} / \mathrm{min}$ \\
\hline Tool tilt & \multicolumn{2}{c}{$2^{\circ}$} \\
\hline
\end{tabular}

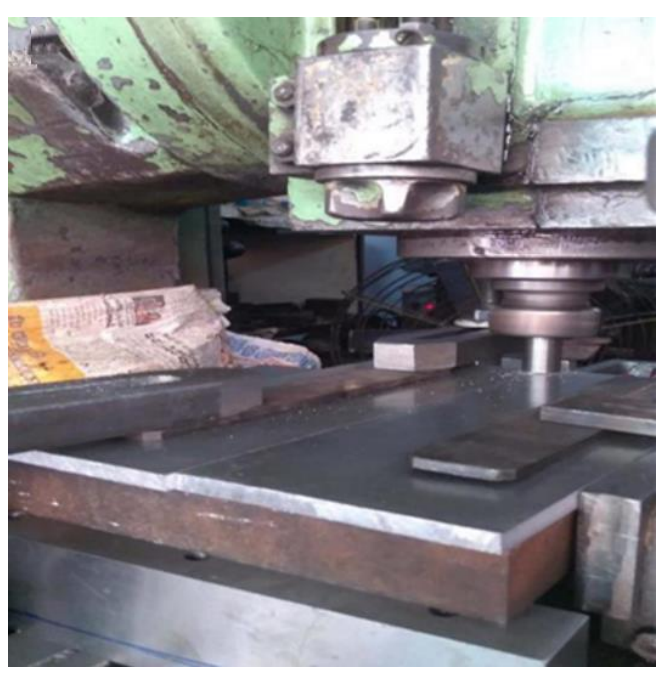

a

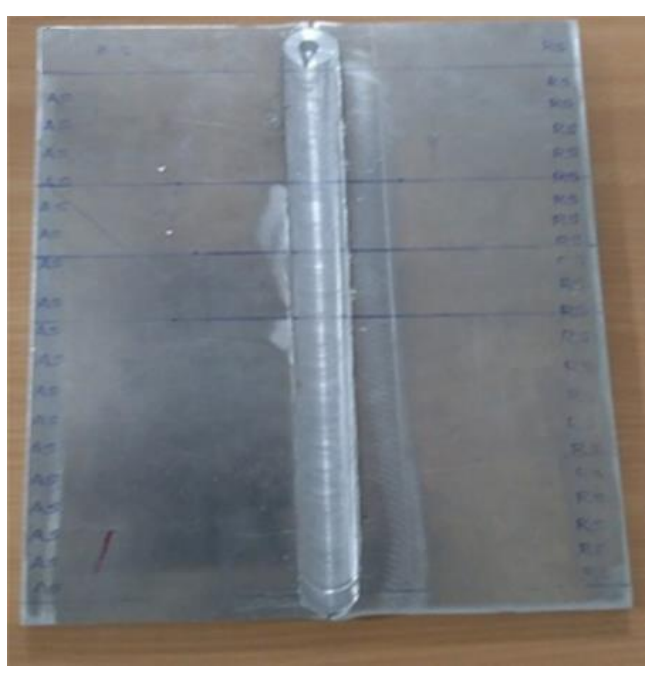

b

Fig. 1 Images showing a) friction stir welding machine and b) welded joint

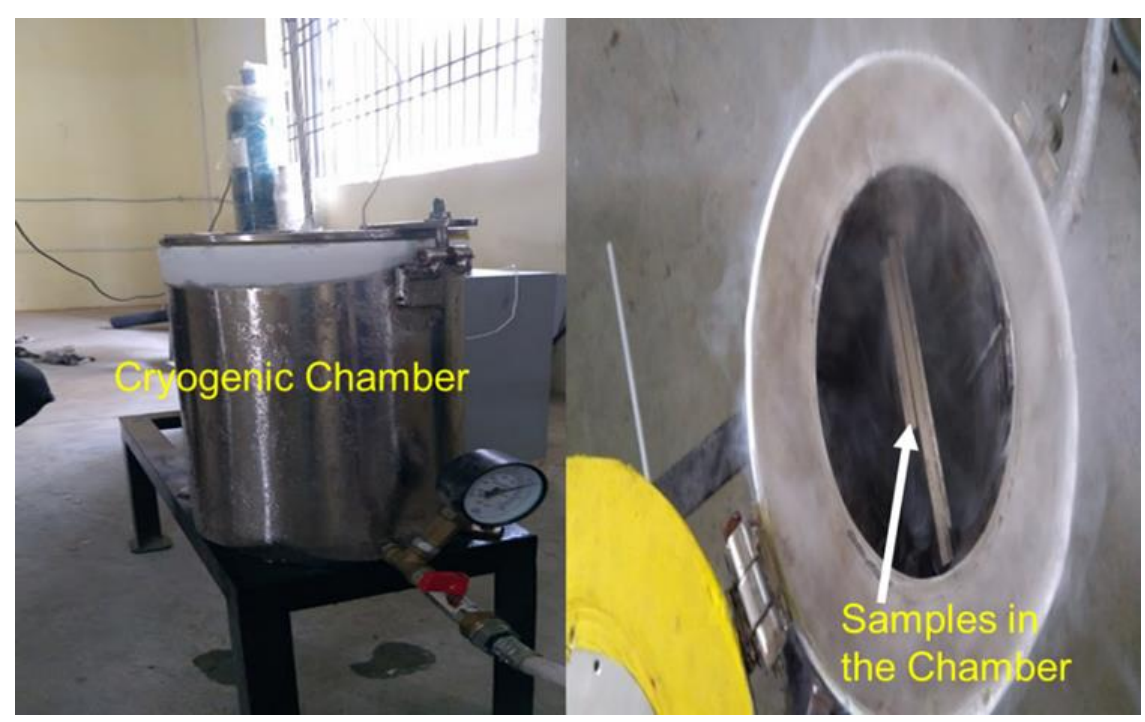

Fig. 2 Cryogenic chamber used for cryogenic treatment 


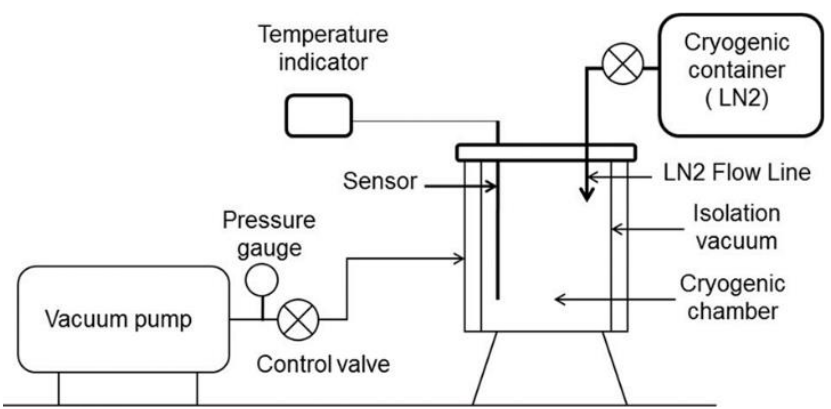

Fig. 3 Illustration of cryogenic treatment

Weld microstructures were examined using stereo and optical microscopy. Samples were carefully prepared to the required sizes from the weld and then polished using different grades of emery papers. Final polishing was carried out using diamond compound (1 micrometer particle size) in a disk polishing machine. The polished samples were etched using standard Keller's reagent ( $5 \mathrm{ml} \mathrm{HNO3,} 2 \mathrm{ml}$ $\mathrm{HF}, 3 \mathrm{ml}$. HCL, and $190 \mathrm{ml}$ distilled water) to under-stand the macro and micro-structures of the weld. The samples for salt fog corrosion test were made from friction stir welded joints using electrical discharge machine. The dimensions of the test specimens were $70 \mathrm{~mm} \times 10 \mathrm{~mm} \times 9.5 \mathrm{~mm}$. NaCl salt solution was made with $\mathrm{pH}$ values of 2,7 and 11 . A digital ELICO $\mathrm{pH}$ meter was used to measure the $\mathrm{pH}$ values of the solution. The salt spray test was performed as per ASTM B117 standards and corrosion rate was evaluated as per ASTM G1. The setup of salt fog corrosion test is presented in Fig. 4. Basically, the test procedure involves the spraying of a salt solution onto the samples being tested, which are kept inside a temperature-controlled glass chamber. The specimens were hung from glass racks inside the salt fog chamber, following which the salt containing solution was sprayed as a very fine fog mist over the samples. The $\mathrm{NaCl}$ solution was supplied from a reservoir to nozzles. The solution was mixed with compressed air at the nozzle and this compressed air atomized the $\mathrm{NaCl}$ solution into a fog at the nozzle. As the spray was continuous, the samples were continuously exposed to the salt fog and therefore uniformly subjected to corrosion. The corrosion rate of the specimens was calculated by weight loss measurement. The initial weight of the specimen before test $\left(w_{i}\right)$ was noted and then the specimen was sprayed with $\mathrm{NaCl}$ solution for different spraying times $(24,48$, and $72 \mathrm{~h})$. The corroded specimens were properly cleaned to the required extent, dried and weighed again to obtain the final weight $\left(w_{f}\right)$. The loss of weight $(w)$ can be measured using the following relation, $w=w_{i}-w_{f}$. Where, $w$ is the weight loss in grams, $w_{i}$ is the initial weight before test in grams and $w_{f}$ is the final weight after test in grams. The corrosion rate of the specimens was calculated using the following equation:

$$
\text { Corrosion rate }\left(\frac{\mathrm{mm}}{\text { year }}\right)=\frac{8.76 \times 10^{4} \times w}{A \times D \times T} \text {, }
$$

where: $A$ is the surface area of the specimen in $\mathrm{cm}^{2} ; D$ is the density of the material, $2.66 \mathrm{~g} \mathrm{~cm}^{-3} ; T$ is the spraying time in hours, h.

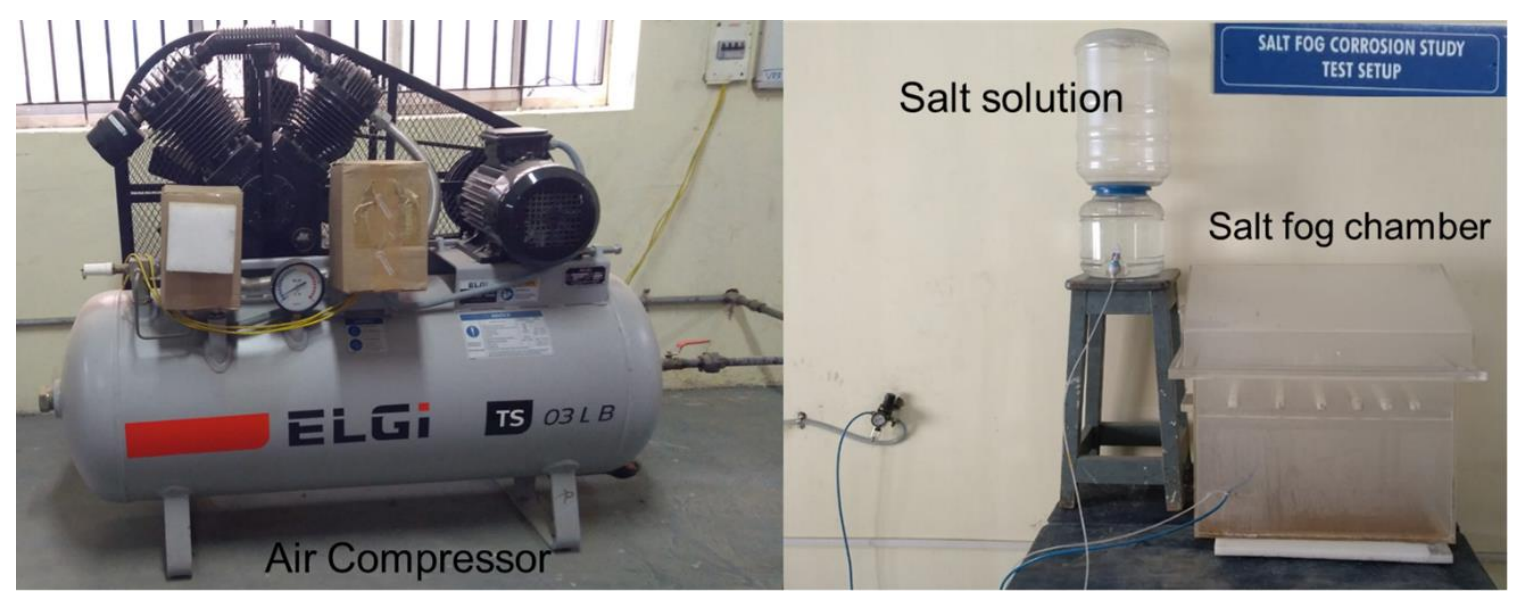

Fig. 4 Salt fog corrosion test setup

\section{Results and discussion}

\subsection{Light microscopy}

The macrostructure of the weld on transverse section is shown in Fig. 5, a. Various microstructural zones of importance on this macrograph are clearly observed.

Though friction stir welded joints are free from solidification-related defects, FSW joints are prone to other weld defects such as pin hole, tunnel defect, piping defect, kissing bond, zigzag line and cracks, due to improper flow of metal and insufficient consolidation of metal in the FSW (weld nugget) region [23]. As it can be seen, no obvious welding defects were found in the weld, indicating that sound weld was obtained. Furthermore, the macrograph revealed the formation of an onion structured weld nugget, which is considered to be a common feature in friction stir welded aluminum alloys. The base material was characterized by large pancake shaped grains (Fig. 5, b) typical of a hot rolled structure. The weld nugget, where the highest degree of deformation and the highest temperatures take place, was characterised by fine and equiaxed grains (Fig. 5, c) resulting from recrystallisation. The transition zone between the base material and weld nugget was characterized by a highly deformed structure as shown in Fig. 5, c. The microstructure of HAZ is presented in Fig. 5, d. As it can be seen, the HAZ retained the same grain structure as the parent material. 

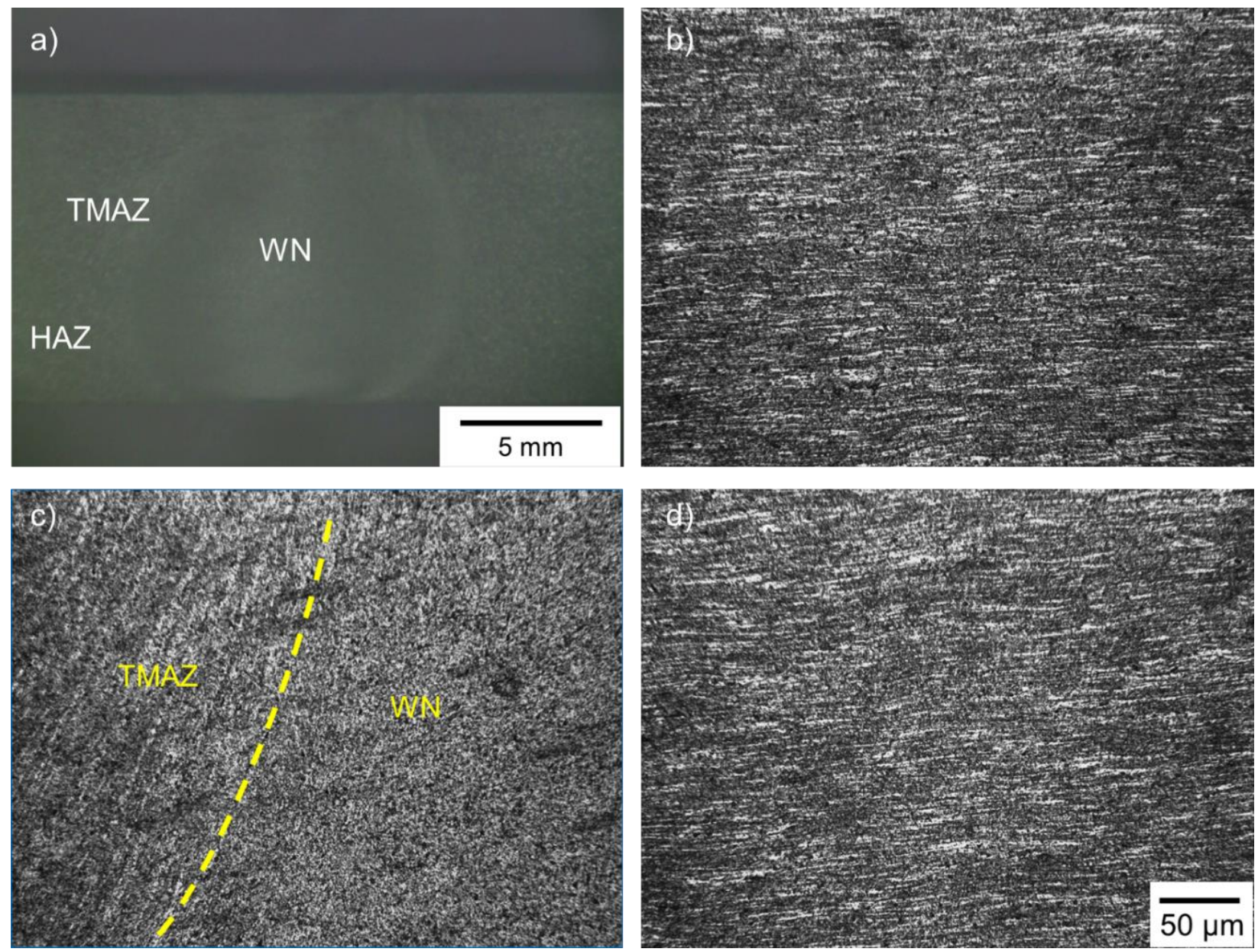

Fig. 5 Typical optical micrographs of friction stir welded AA 5083-H321: a) macrostructure, b) base material, c) weld nugget showing recrystallized grains and TMAZ exhibiting deformed grains (d) HAZ

\subsection{Corrosion behavior}

The corrosion rates of BM, FSW, CT BM and CT FSW for $\mathrm{pH}$ value of 11 at three different times of exposure (24, 48 and $72 \mathrm{~h}$ ) are shown in Table 3 . The variation in corrosion rate with respect to the time of exposure for $\mathrm{pH}$ value of 11 is presenetd in Fig. 6, a. It is understood that the friction stir welds experienced more corrosion rate than that of the base material. Furthermore, it was also observed that the corrosion rate in both base mterial and the welds decreases with increase in time of exposure. This could be due to the protective oxide layer forms on the surface of the samples. As it can be clearly observed, the cryogenic treatment performed on both base material and friction stir welds was found to improve corrosion resistance. The lowest corrosion rate was recoreded in CT BM at $72 \mathrm{~h}$ and the highest corrosion rate was identified in FSW at $24 \mathrm{~h}$. The corrosion rates for $\mathrm{pH}$ values of 7 and 2 are presented in Table 4 and Table 5 respectively.

Corrosion rates for $p H$ value of 11 at various times of exposure

Table 3

\begin{tabular}{|c|c|c|c|c|c|c|c|c|}
\hline \multirow{2}{*}{$\begin{array}{l}\text { S. } \\
\text { No. }\end{array}$} & \multirow{2}{*}{ Material } & \multirow{2}{*}{ Sample } & \multirow{2}{*}{$\begin{array}{l}\text { Weight before } \\
\text { corrosion, } g\end{array}$} & \multicolumn{3}{|c|}{ Weight after corrosion, $\mathrm{g}$} & \multirow{2}{*}{ Weight loss, $\mathrm{g}$} & \multirow[t]{2}{*}{ Corrosion rate, $\mathrm{mm} /$ year } \\
\hline & & & & $24 \mathrm{~h}$ & $48 \mathrm{~h}$ & $72 \mathrm{~h}$ & & \\
\hline \multirow{3}{*}{1} & \multirow{3}{*}{$\mathrm{BM}$} & S1 & 17.24414 & 17.24118 & - & - & 0.00296 & 0.1216 \\
\hline & & S2 & 17.35405 & - & 17.35093 & - & 0.00312 & 0.0641 \\
\hline & & S3 & 17.32063 & - & - & 17.31828 & 0.00235 & 0.0321 \\
\hline \multirow{3}{*}{2} & \multirow{3}{*}{ FSW } & S1 & 16.19724 & 16.19375 & - & - & 0.00349 & 0.1434 \\
\hline & & S2 & 16.10613 & - & 16.10148 & - & 0.00465 & 0.0955 \\
\hline & & S3 & 16.24226 & - & - & 16.23988 & 0.00238 & 0.0326 \\
\hline \multirow{3}{*}{3} & \multirow{3}{*}{ CT BM } & S1 & 17.28870 & 17.28684 & - & - & 0.00186 & 0.0764 \\
\hline & & S2 & 17.31309 & - & 17.31050 & - & 0.00259 & 0.0532 \\
\hline & & S3 & 17.29649 & - & - & 17.29433 & 0.00216 & 0.0295 \\
\hline \multirow{3}{*}{4} & \multirow{3}{*}{ CT FSW } & S1 & 16.04503 & 16.04211 & - & - & 0.00292 & 0.1199 \\
\hline & & S2 & 16.98319 & - & 16.98318 & - & 0.00354 & 0.0727 \\
\hline & & S3 & 16.10564 & - & - & 16.10351 & 0.00213 & 0.0291 \\
\hline
\end{tabular}


Corrosion rates for $\mathrm{pH}$ value of 7 at various times of exposure

\begin{tabular}{|c|c|c|c|c|c|c|c|c|}
\hline \multirow{2}{*}{ S. No. } & \multirow{2}{*}{ Material } & \multirow{2}{*}{ Sample } & \multirow{2}{*}{$\begin{array}{l}\text { Weight before } \\
\text { corrosion, } g\end{array}$} & \multicolumn{3}{|c|}{ Weight after corrosion, $g$} & \multirow{2}{*}{ Weight loss, g } & \multirow{2}{*}{ Corrosion rate, $\mathrm{mm} /$ year } \\
\hline & & & & $24 \mathrm{~h}$ & $48 \mathrm{~h}$ & $72 \mathrm{~h}$ & & \\
\hline \multirow{3}{*}{1} & \multirow{3}{*}{$\mathrm{BM}$} & S1 & 17.24118 & 17.23651 & - & - & 0.00467 & 0.1918 \\
\hline & & S2 & 17.35093 & - & 17.34424 & - & 0.00669 & 0.1374 \\
\hline & & S3 & 17.31828 & - & - & 17.31174 & 0.00654 & 0.0895 \\
\hline \multirow{3}{*}{2} & \multirow{3}{*}{ FSW } & S1 & 16.19375 & 16.18730 & - & - & 0.00645 & 0.2649 \\
\hline & & S2 & 16.10148 & - & 16.09428 & - & 0.00720 & 0.1479 \\
\hline & & S3 & 16.23988 & - & - & 16.23406 & 0.00582 & 0.0797 \\
\hline \multirow{3}{*}{3} & \multirow{3}{*}{ CT BM } & S1 & 17.28455 & 17.28127 & - & - & 0.00328 & 0.1347 \\
\hline & & S2 & 17.30840 & - & 17.30371 & - & 0.00469 & 0.0963 \\
\hline & & S3 & 17.29012 & - & - & 17.28599 & 0.00413 & 0.0565 \\
\hline \multirow{3}{*}{4} & \multirow{3}{*}{ CT FSW } & S1 & 16.04047 & 16.03547 & - & - & 0.00500 & 0.2054 \\
\hline & & S2 & 15.97648 & - & 15.96964 & - & 0.00684 & 0.1405 \\
\hline & & S3 & 16.10001 & - & - & 16.09519 & 0.00482 & 0.0660 \\
\hline
\end{tabular}

Table 5

Corrosion rates for $p H$ value of 2 at various times of exposure

\begin{tabular}{|c|c|c|c|c|c|c|c|c|}
\hline \multirow{2}{*}{ S. No. } & \multirow{2}{*}{ Material } & \multirow{2}{*}{ Sample } & \multirow{2}{*}{$\begin{array}{l}\text { Weight before } \\
\text { corrosion, } \mathrm{g}\end{array}$} & \multicolumn{3}{|c|}{ Weight after corrosion, $\mathrm{g}$} & \multirow{2}{*}{ Weight loss, g } & \multirow{2}{*}{ Corrosion rate, $\mathrm{mm} /$ year } \\
\hline & & & & $24 \mathrm{~h}$ & $48 \mathrm{~h}$ & $72 \mathrm{~h}$ & & \\
\hline \multirow{3}{*}{1} & \multirow{3}{*}{$\mathrm{BM}$} & S1 & 17.23651 & 17.23091 & - & - & 0.00560 & 0.2300 \\
\hline & & S2 & 17.34424 & - & 17.33437 & - & 0.00987 & 0.2027 \\
\hline & & S3 & 17.31174 & - & - & 17.30263 & 0.00911 & 0.1247 \\
\hline \multirow{3}{*}{2} & \multirow{3}{*}{ FSW } & S1 & 16.18730 & 16.17965 & - & - & 0.00765 & 0.3143 \\
\hline & & $\mathrm{S} 2$ & 16.09428 & - & 16.08477 & - & 0.00951 & 0.1953 \\
\hline & & S3 & 16.23406 & - & - & 16.22672 & 0.00734 & 0.1005 \\
\hline \multirow{3}{*}{3} & \multirow{3}{*}{ CT BM } & S1 & 17.28127 & 17.27771 & - & - & 0.00356 & 0.1463 \\
\hline & & $\mathrm{S} 2$ & 17.30371 & - & 17.29946 & - & 0.00425 & 0.0873 \\
\hline & & S3 & 17.28599 & - & - & 17.28270 & 0.00329 & 0.0451 \\
\hline \multirow{3}{*}{4} & \multirow{3}{*}{ CT FSW } & S1 & 16.03547 & 16.02985 & - & - & 0.00562 & 0.2309 \\
\hline & & S2 & 15.96964 & - & 15.96253 & - & 0.00711 & 0.1461 \\
\hline & & S3 & 16.09519 & - & - & 16.08956 & 0.00563 & 0.0771 \\
\hline
\end{tabular}

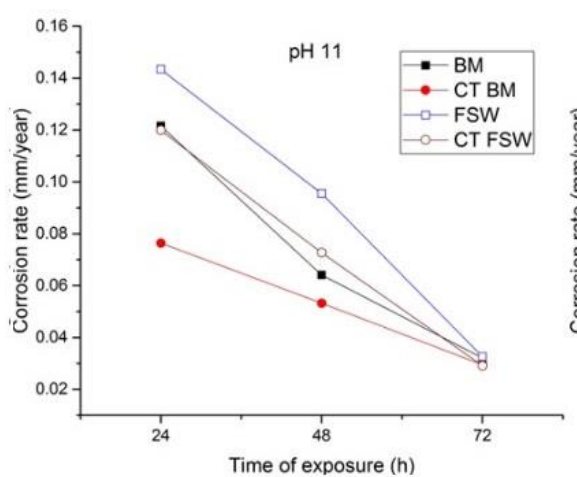

a

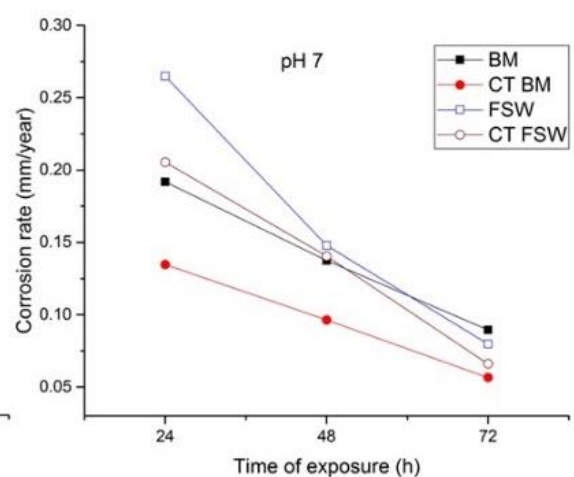

b

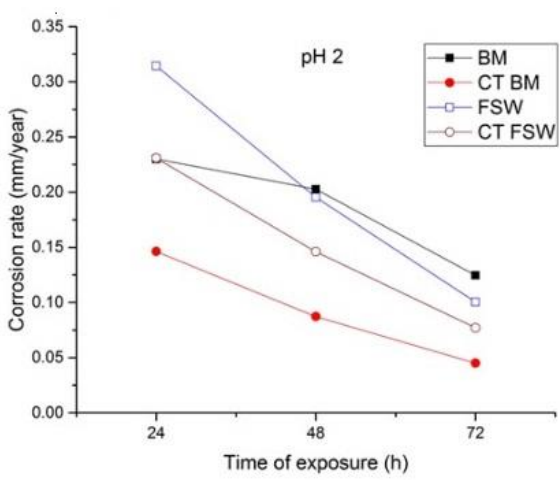

c

Fig. 6 Variations in corrosion rate with time of exposure at various $\mathrm{pH}$ values: a) $\mathrm{pH} 11, \mathrm{pH} 7$ and $\mathrm{pH} 2$

Variations in corrosion rate with respect to time of exposure are also shown in Fig. 6. It was also revealed that the friction stir welds were found to exhibit more corrosion rate than that of the base material for all $\mathrm{pH}$ values. Furthermore, it has been observed that the corrosion rate is more in acidic solution $(\mathrm{pH} 2)$ than that of neutral solution $(\mathrm{pH} 7)$ and basic solution ( $\mathrm{pH} 11)$.

Microstructures of corrosion tested base material and friction stir weld nugget before and after cryogenic treatment at $\mathrm{pH}$ value 11,7 and 2 for corresponding times of exposure are given in Figs. 7, 8 and 9 respectively. At all the $\mathrm{pH}$ values, corrosion attack was found to be more for $24 \mathrm{~h}$ of exposure time and less for $72 \mathrm{~h}$ of exposure time. It was also observed that the attack is predominant in friction stir welds compared that of base material. As it can be clearly seen, the cryogenic treatment resulted in significant reduction in crrosion on both base material and the welds. The samples exposed to acedic environment (with $\mathrm{pH} 2$ ) 
experienced severe corrosion attack compared to that of the samples exposed to neutral (with $\mathrm{pH}$ 7) and basic environment (with pH 11).
BM

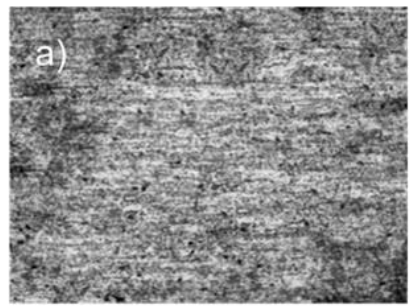

$48 \mathrm{~h}$

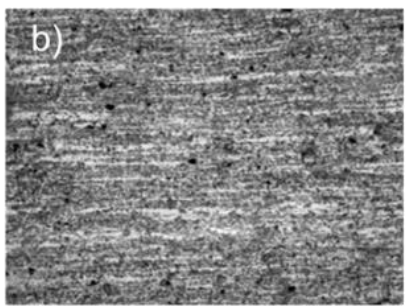

$72 \mathrm{~h}$

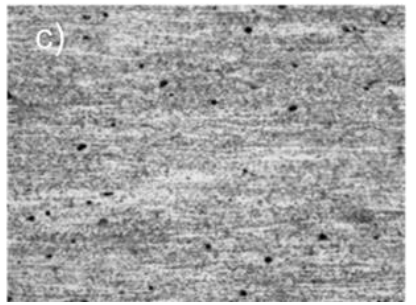

СТ BM
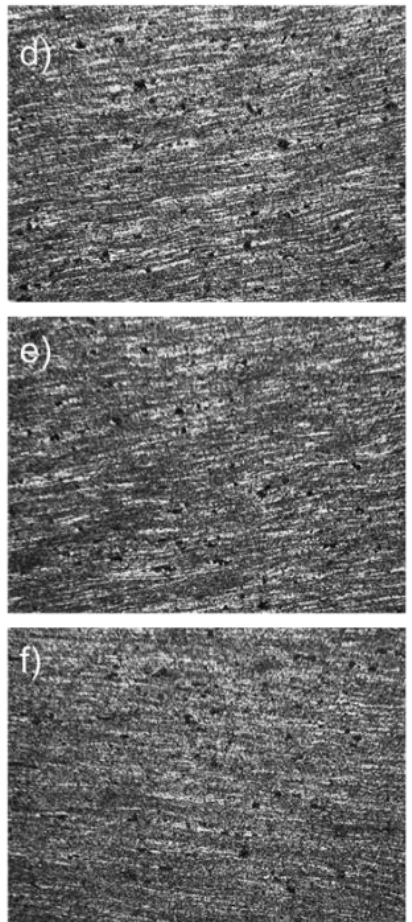

FSW
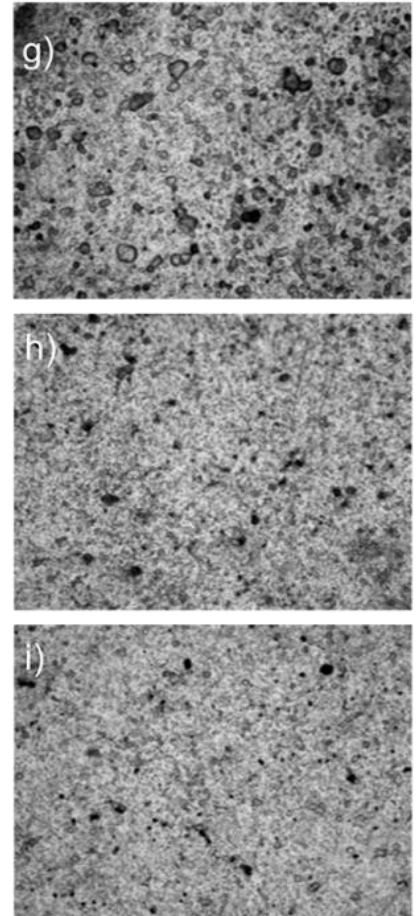

CT FSW
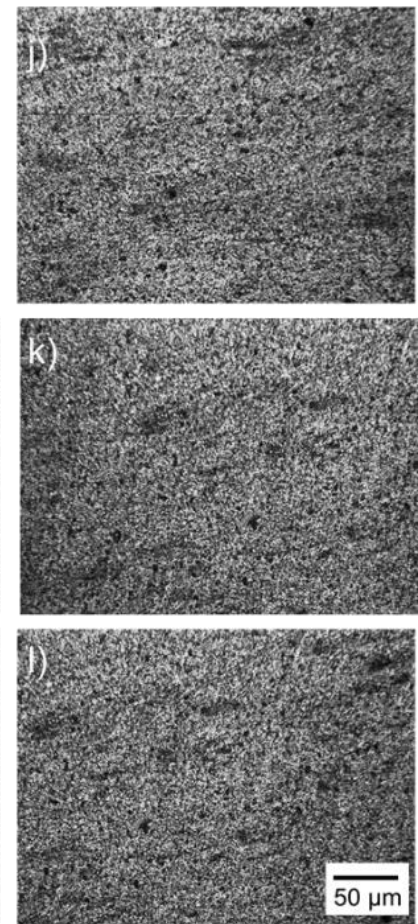

Fig. 7 Optical micrographs at pH 11 for BM (a, b, c), CT BM (d, e, f), FSW (g, h, i) and CT FSW (j, k, l) for corresponding spraying times $(24,48$ and $72 \mathrm{~h})$

BM

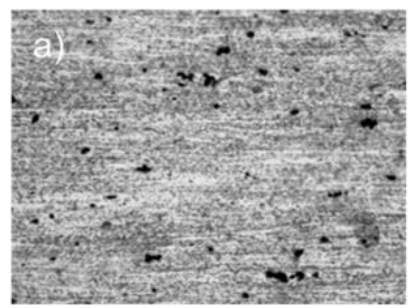

$48 \mathrm{~h}$

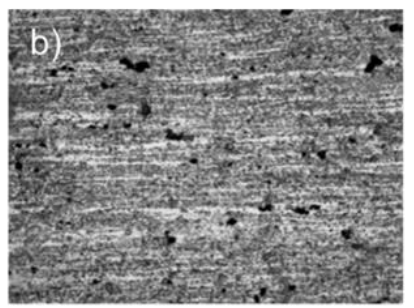

$72 \mathrm{~h}$

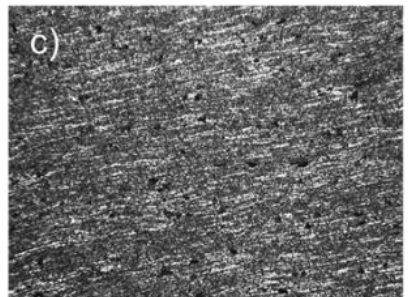

Ст BM
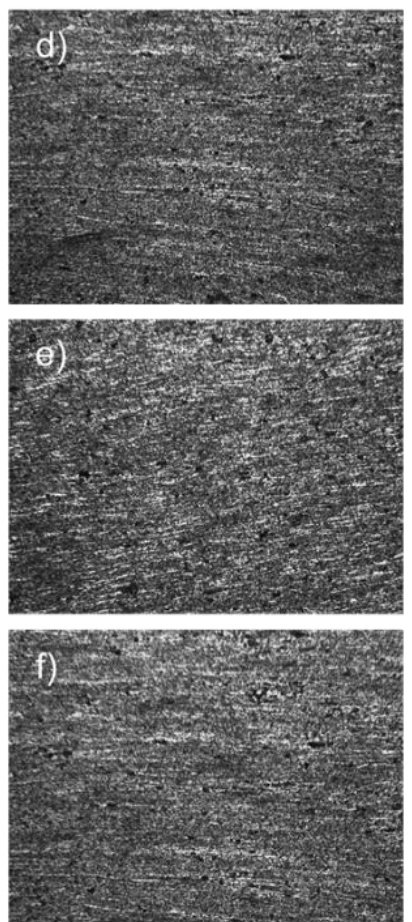

FSW
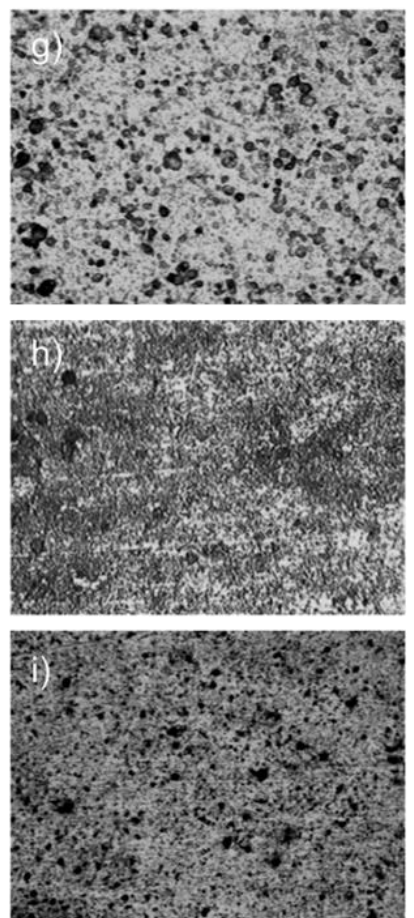

CT FSW
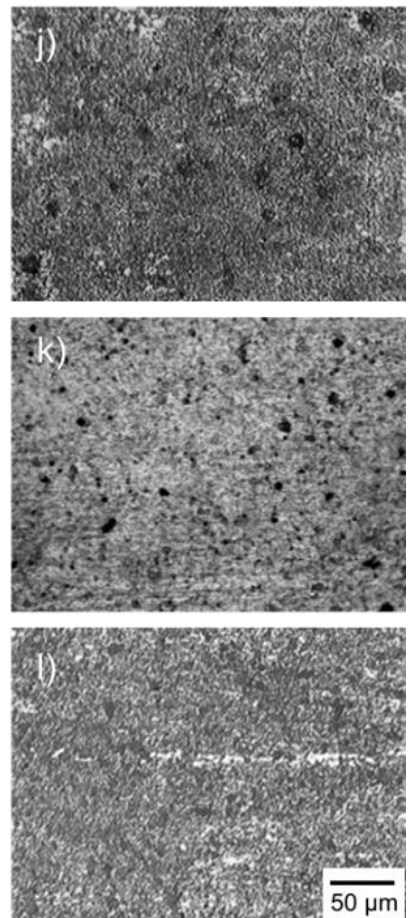

Fig. 8 Optical micrographs at pH 7 for BM (a, b, c), CT BM (d, e, f), FSW (g, h, i) and CT FSW (j, k, l) for corresponding spraying times $(24,48$ and $72 \mathrm{~h})$ 
BM

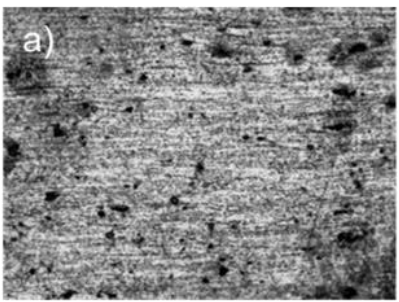

$48 \mathrm{~h}$

$72 \mathrm{~h}$
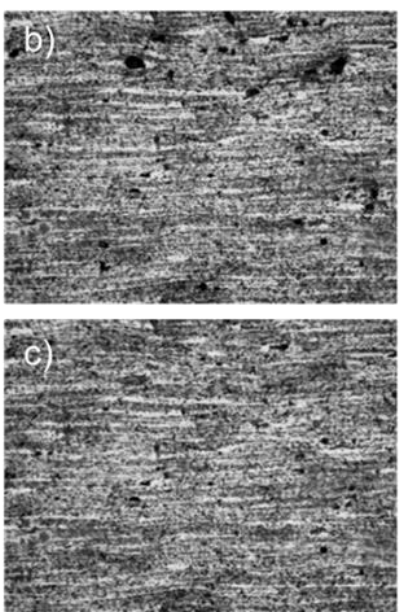

CT BM
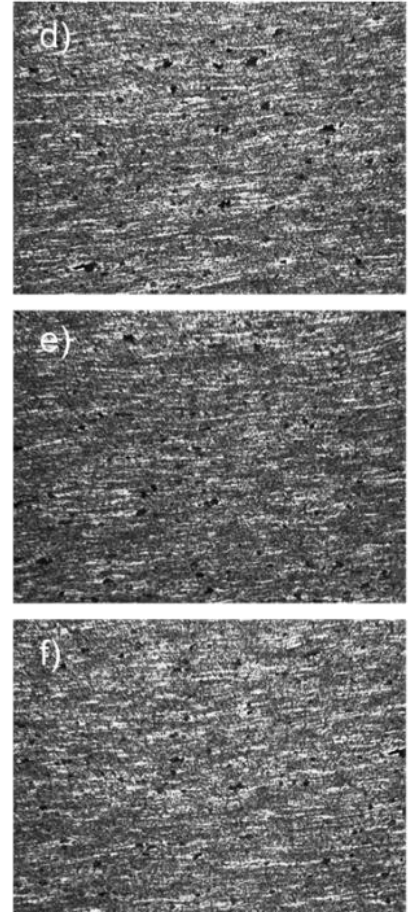

FSW
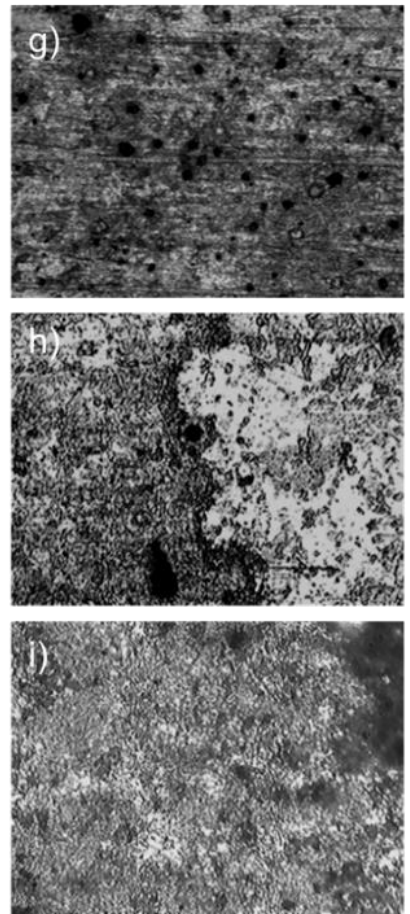

CT FSW
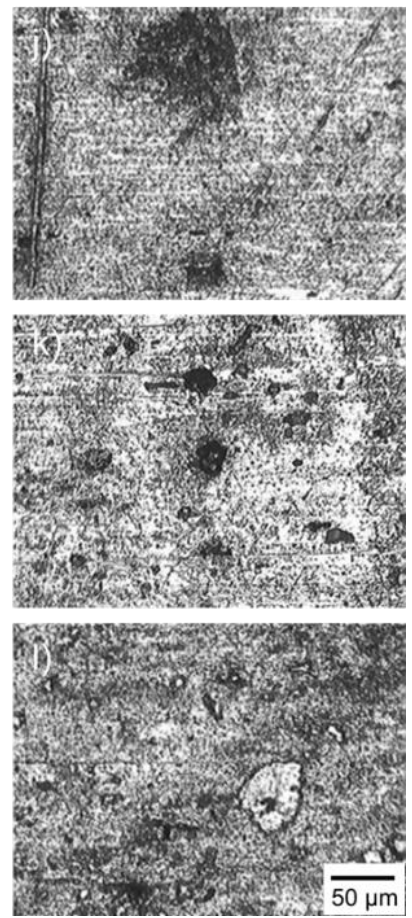

Fig. 9 Optical micrographs at pH 2 for BM (a, b, c), CT BM (d, e, f), FSW (g, h, i) and CT FSW (j, k, l) for corresponding spraying times $(24,48$ and $72 \mathrm{~h})$

\section{Conclusions}

1. Full penetration sound welds were produced on $10 \mathrm{~mm}$ thick AA5083-H321 aluminum alloy plates and the welds were evaluated for salt fog corrosion behavior with and without cryogenic treatment.

2. The friction stir welds were found to exhibit more corrosion rate compared to that of base material. However, the corrosion rate of both base material and the welds decreased with increase in time of exposure.

3. The cryogenic treatment carried out on both base material and the welds resulted in reduction in corrosion rate.

4. Corrosion rate increases, both in base material and friction stir welds, with decrease in $\mathrm{pH}$ value of the salt solution.

\section{Acknowledgements}

The authors are thankful to Dr. T. Venkateswaran, Scientist F, VSSC, Trivendrum, India, for his valuable suggestions.

\section{References}

1. Thomas, W. M.; Nicholas, E. D.; Needham, J. C.; Murch, M. G.; Temple-Smith, P.; Dawes, C. J. 1991. GB Patent 9125978.8.

2. James, M. N.; Hattingh, D. G.; Bradley, G. R. 2003. Weld tool travel speed effects on fatigue life of friction stir welds in 5083 aluminum, International journal of fatigue 25:1389-1398.

http://dx.doi.org/10.0.1016/S0142-1123(03)00061-6.

3. Mishra, R. S.; Ma, Z.Y. 2005. Friction stir welding and processing, Mater. Sci. Eng. R 50: 1-78.

http://dx.doi.org/10.1016/j.mser.2005.07.001
4. Nandan, R.; DebRoy, T.; Bhadeshia, H. K. D. H. 2008 Recent advances in friction-stir welding - process, weldment structure and properties, Prog. Mater Sci. 53: 9801023.

https://doi.org/10.1016/j.pmatsci.2008.05.001.

5. Kumar, R.; Singh, K.; Pandey, S. 2012. Process forces and heat input as function of process parameters in AA5086 friction stir welds, Trans. Nonferrous Met. Soc. China 22: 288-298.

https://doi.org/10.1016/S1003-6326 (11)61173-4.

6. Srinivasa Rao, T.; Madhusudhan Reddy, G.; Koteswara Rao, S. R. 2016. Studies on variations in microstructure and hardness of AA7075-T651 aluminum alloy friction stir welds, Metall. Ital. 108: 29-35.

7. Thamilarasan, K.; Rajendraboopathy, S.; Madhusudhan Reddy, G.; Srinivasa Rao, T.; Koteswara Rao, S. R. 2016. Salt fog corrosion behavior of friction stir welded AA2014-T651 aluminum alloy, Mater. Test. 58: 932-938. https://doi.org/10.3139/120.110941.

8. Srinivasa Rao, T.; Madhusudhan Reddy, G.; Koteswara Rao, S. R. 2015. Microstructure and mechanical properties of friction stir welded AA7075-T651 aluminum alloy thick plates, Trans. Nonferrous Met. Soc. China 25: 1770-1778.

http://dx.doi.org/10.1016/S1003-6326(15)63782-7.

9. Koilraj, M.; Sundareswaran, V.; Vijayan, S.; Koteswara Rao, S. R. 2012. Friction stir welding of dissimilar aluminum alloys AA2219 to AA5083optimization of process parameters using Taguchi technique, Mater. Des. 42: 1-7.

https://doi.org/10.1016/j.matdes.2012.02.016.

10. Dawood, H. I.; Mohammed, K. S.; Rahmat, A.; Uday, M. B. 2015. Effect of small tool pin profiles on microstructures and mechanical properties of 6061 aluminum 
alloy by friction stir welding, Trans. Nonferrous Met. Soc. China 25: 2856-2865. https://doi.org/10.1016/S1003-6326 (15)63911-5.

11. Zucchi, F.; Trabanelli, G.; Grassi, V. 2001. Pitting and stress corrosion cracking resistance of friction stir welded AA 5083, Mater. Corros. 52: 853-859. https://doi.org/10.1002/15214176(200111)52:11<853: AID-MACO853>3.0.CO;2-1.

12. Lumsden, J. B.; Mahoney, M. W.; Rhodes, C. G.; Pollock, G. A. 2003. Corrosion behavior of friction-stirwelded AA7050-T7651, Corrosion 59: 212-219. https://doi.org/10.5006/1.3277553.

13. Frankel, G. S.; Xia, Z. 1999. Localized corrosion and stress corrosion cracking resistance of friction stir welded Al alloy 5454, Corrosion 55: 139-150. https://doi.org/10.5006/1.3283974.

14. Squillace, A.; Fenzo, A. D.; Giorleo, G.; Bellucci, F. 2004. A comparison between FSW and TIG welding techniques: modifications of microstructure and pitting corrosion resistance in AA 2024-T3 butt joints, J. Mater. Process. Tech. 152: 97-105. https://doi.org/10.1016/j.jmatprotec.2004.03.022.

15. Srinivasa Rao, T.; Madhusudhan Reddy, G.; Srinivasa Rao, G.; Koteswara Rao, S. R. 2014. Studies on salt fog corrosion behavior of friction stir welded AA7075-T651 aluminum alloy. Int. J. Mater. Res. 105: 375-385. http://dx.doi.org/10. 10.3139/146.111033.

16. Baldissera, P.; Delprete, C. 2008. Deep cryogenic treatment: a bibliographic review, The Open Mechanical Engineering Journal 2: 1-11. http://dx.doi.org/10.2174/1874155X00802010001.

17. Kalia, S. 2010. Cryogenic processing: a study of materials at low temperatures, Journal of Low Temperature Physics 158: 934-945. https://doi.org/10.1007/s10909-009-0058-x.

18. Gu, K.; Zhang, H.; Zhao, B.; Wang, J.; Zhou, Y.; Li, Z. 2013. Effect of cryogenic treatment and aging treatment on the tensile properties and microstructure of $\mathrm{Ti}-$ 6Al-4V alloy, Materials Science and Engineering A 584: $170-176$. https://doi.org/10.1016/j.msea.2013.07.021.

19. Wang, P.; Lu, W.; Wang, Y.; Liu, J.; Zhang, R. 2011. Effects of cryogenic treatment on the thermal physical properties of $\mathrm{Cu} 76.12 \mathrm{Al} 23.88$ alloy, Rare Metals 30: 644-649. https://doi.org/10.1007/s12598-011-0443-x.

20. Wang, J.; Xue, X.; Yang, Z.; Zhang, H.; Zhou, Y. 2011. Effect of cryogenic treatments on mechanical properties of 2A11 Aluminum alloy, Advanced Materials Research 146-147: 1646-1650.

https://doi.org/10.4028/www.scientific.net/AMR.146147.1646.
21. Lulay, K. E.; Khan, K.; Chaaya, D. 2002. The effect of cryogenic treatments on 7075 Aluminum alloy, Journal of Materials Engineering and Performance 11: 479480. https://doi.org/10.1361/105994902770343683.

22. Wierszyłowski, I.; Wieczorek, S.; Andrzejewska, E.; Marcinkowska, A. 2008. The influence of deep cryogenic treatment after supersaturation of $\mathrm{Al} 4.7 \% \mathrm{Cu}$ alloy on transformation during ageing, Studies of Dilatometry, DSC, Hardness and XRD, Defect and Diffusion Forum 273-276: 724-730.

https://doi.org/10.4028/www.scientific.net/DDF.273276.724 .

23. Xie, G. M.; Ma, Z. Y.; Luo, Z. A.; Xue, P.; Wang, G. D. 2011. Effect of rotation rate on microstructures and mechanical properties of FSW Mg-Zn-Y-Zr Alloy Joints, J. Mater. Sci. Technol. 27: 1157-1164. http://www.jmst.org/EN/Y2011/V27/I12/1157.

V. Neelamegam, B. Govindasamy Bhavani, M. Muthukrishnan, S. Rao Tadivaka

\section{INVESTIGATION ON CORROSION BEHAVIOR OF CRYOGENICALLY TREATED FRICTION STIR WELDED AA5083}

\section{S u m m a r y[-1]}

The aluminum alloy 5083 is widely used as a structural material in marine applications due to very good corrosion resistance and low temperature mechanical properties. Friction stir welding, being a solid state process, offers several benefits over the traditional fusion welding processes. In this study, $10 \mathrm{~mm}$ thick AA5083-H321 plates were successfully friction stir welded and the welds were investigated for corrosion behavior using salt fog corrosion tests. The friction stir welds exhibited more corrosion rate compared to that of the base material. However, the corrosion rate was observed to decrease with increase in time of exposure. The cryogenic treatment was found to improve corrosion resistance of the base material and the welds. Furthermore, the corrosion rate increases with decrease in $\mathrm{pH}$ value of the salt solution. By and large, it is determined that the cryogenic treatment advantageously effects the corrosion behavior.

Key words: AA 5083 aluminum alloy, cryogenic treatment, friction stir welding, corrosion behavior, microstructures.

Received June 13, 2019

Accepted October 14, 2020

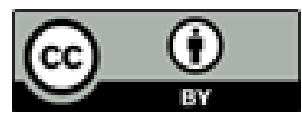

This article is an Open Access article distributed under the terms and conditions of the Creative Commons Attribution 4.0 (CC BY 4.0) License (http://creativecommons.org/licenses/by/4.0/). 